\title{
RNU, Rat Strain
}

National Cancer Institute

\section{Source}

National Cancer Institute. RNU, Rat Strain. NCI Thesaurus. Code C122237.

An athymic, nude, outbred rat strain derived at the laboratories of the $\mathrm{NIH}$ animal genetic resource in 1979-1980. 